\title{
Digital exclusion as a hindrance to the emergence of the information society: the case of Poland
}

\begin{abstract}
There is no doubt, that digital transformation (knowledge-based transformation) has emerged as the crucial megatrend in modern civilization. Artificial intelligence (AI), machines and autonomous vehicles, the Internet of Things (IoT), financial technology (Fin/Tech), smart investing and the analysis and processing of big data are the most recent manifestations of this trend, but not the only ones. All of these phenomena have led to the emergence and continuing development of the so-called 'Information Society' (IS), which refers to a new type of social organization that is clearly distinct from the earlier forms of society. In this new society, information and knowledge play an essential role in facilitating the Knowledge-Based Economy (KBE), where information is collected, transmitted and processed in a faster and more effective manner, and can subsequently be used to foster accelerated economic growth. Unfortunately, the problem of digital exclusion still occurs, also in Poland. The author in the conclusion comes to opinion that people who are digitally excluded find it much more difficult to overcome psychological rather than technical barriers to having access to the Internet and learning basic computer skills. This situation calls for urgent improvement. In the modern information society, a lack of basic knowledge about computers translates into partial or total digital illiteracy and makes it difficult to perform a range of everyday tasks. It is therefore essential in Poland to prevent digital exclusion. People who do not use the Internet are socially and professionally limited, or virtually handicapped, which results in quantifiable economic losses. This translates to lower creativity and innovativeness and reduced revenue of state budget, and impedes the competitiveness of the economy and the development of a post-modern, post-industrial social model. The main research goal is to show the causes of the phenomenon of digital exclusion in Poland and ways to counteract it. In the course of the research, the most frequently used method was causal and effect analysis as well as institutional and legal analysis. Elements of the decision-making, historical, comparative and statistical methods were also used.
\end{abstract}

Key words: digital exclusion, social media, E-commerce, Internet, GDP, socio-economic development, globalisation

\section{Introduction}

$\Delta 11$ around the globe, Information and Communication Technologies (ICT) have Atriggered sweeping changes, the pace, range and significance of which are unprecedented in human history. Digital transformation (knowledge-based transformation) has emerged as the crucial megatrend in modern civilization. Artificial intelligence (AI), machines and autonomous vehicles, the Internet of Things (IoT), financial technology (Fin/Tech), smart investing and the analysis and processing of big data are the most recent manifestations of this trend, but not the only ones. All of these phenomena have led to the emergence and continuing development of the so-called 'Information 
Society' (IS), which refers to a new type of social organization that is clearly distinct from the earlier forms of society. In this new society, information and knowledge play an essential role in facilitating the Knowledge-Based Economy (KBE), where information is collected, transmitted and processed in a faster and more effective manner, and can subsequently be used to foster accelerated economic growth. For KBE to develop, an extensive infrastructure is essential, in order to allow the online transfer of data and thus build a computerized society by facilitating access to the Internet and electronic devices, increasing the need to use these tools and combating the fear, concerns and reluctance to use them that accompanies the arrival of revolutionary new technologies. The number of Internet users around the globe has been growing rapidly over the last decade or so. In 2005, around 1 billion people had access to the Internet. Ten years later, in 2015, this number tripled, reaching 3.2 billion, and it continues to grow today (Statystyki dotyczace..., 2016).

\section{The importance of the Internet in socio-economic development}

The application of ICT in the life of modern humans has gained enormous impetus, as evidenced by the following: "telephones needed around seventy years to reach fifty million users, radio needed thirty-eight years, cellular phones - fifteen years, television - thirteen years, the Internet - four years, and the iPod - three years... Facebook reached 200 million users in under a year, and 1,000,000,000 songs were downloaded to iPods in just nine months. Every two days, more information is created around the globe than was created from the beginning of history until 2004. [...] Ten years ago, you needed seventy-two hours do download a $2 \mathrm{~GB}$ movie, while now this time has shrunk to a mere ten minutes" (Senkus, 2013, p. 44).

This progress has resulted in both business and people's social and cultural lives being largely dependent on the correct operation of modern ICT and an uninterrupted information flow. The analysts who wrote an influential report entitled We are social estimated that, in January 2016, 3.4 billion people had access to the Internet, either by broadband connection or mobile devices, accounting for $46 \%$ of the global population. The number of active users of social media had reached 2.3 billion, and 3.7 billion people were in possession of a cellular phone (51\%). Global network traffic generated from desktops and laptops amounted to $56 \%$ of the total, from cellular phones $-39 \%$ (an impressive $21 \%$ increase compared to 2015 ) and by tablets - 5\% (a $21 \%$ fall compared to 2015) (Digital in 2016..., 2016).

The same report quotes the most recent data available (for 2017) and estimates the number of Internet users at nearly 3.8 billion, which is more than $50 \%$ of the global population. Over 4 billion people are expected to use the Internet at least once a month in 2018. Thus, compared to 2016, the number of active Internet users increased by $10 \%$, social media users by $21 \%$, and smartphone users by $5 \%$. North America and Western Europe continue to be the regions with the highest saturation of Internet connections (Digital in 2017, 2017). 
PP 3 '18 Digital exclusion as a hindrance to the emergence of the information...

Graph 1. Key indicators for the world's Internet users

(selected criteria, data for January 2017)
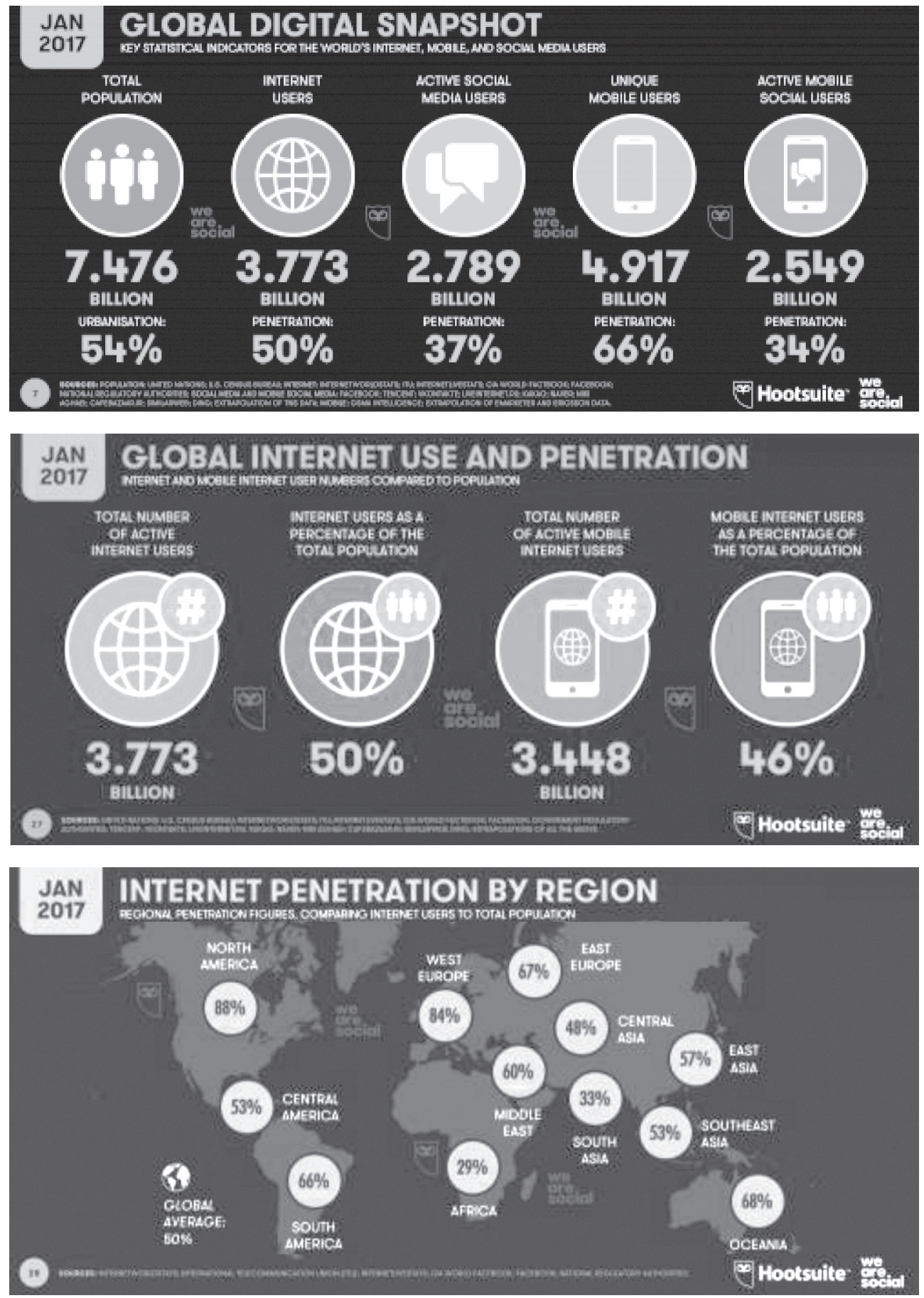

Source: Digital in 2017, 2017. 
However, the most marked increase in access to and usage of the Internet in social and professional life is in East Asia, spearheaded by South Korea, Japan, Singapore, the People's Republic of China, Taiwan and Hong-Kong. China is home to the largest number of Internet users at present, approx. 700 million. The United States comes second, but eMarketer forecasts that it will soon be overtaken by India, which is rapidly developing its access to the Internet and is often the location of subcontractors offering IT services to leading transnational corporations in the IT sector (3 miliardy internautów..., 2014).

Table 1

Top 25 countries, ranked by Internet users, 2013-2018 [millions]

\begin{tabular}{|l|r|r|r|r|r|r|}
\hline & $\mathbf{2 0 1 3}$ & $\mathbf{2 0 1 4}$ & $\mathbf{2 0 1 5}$ & $\mathbf{2 0 1 6}$ & $\mathbf{2 0 1 7}$ & $\mathbf{2 0 1 8}$ \\
\hline 1. China* & 620.7 & 643.6 & 669.8 & 700.1 & 736.2 & 777.0 \\
\hline 2. US** & 246.0 & 252.9 & 259.3 & 264.9 & 269.7 & 274.1 \\
\hline 3. India & 167.2 & 215.6 & 252.3 & 283.8 & 313.8 & 346.3 \\
\hline 4. Brazil & 99.2 & 107.7 & 113.7 & 119.8 & 123.3 & 125.9 \\
\hline 5. Japan & 100,0 & 102.1 & 103.6 & 104.5 & 105.0 & 105.4 \\
\hline 6. Indonezja & 72.8 & 83.7 & 93.4 & 102.8 & 112.6 & 123.0 \\
\hline 7. Russia & 77.5 & 82.9 & 87.3 & 91.4 & 94.3 & 96.6 \\
\hline 8. Germany & 59.5 & 61.6 & 62.2 & 62.5 & 62.7 & 62.7 \\
\hline 9. Mexico & 53.1 & 59.4 & 65.1 & 70.7 & 75.7 & 80.4 \\
\hline 10. Nigeria & 51.8 & 57.7 & 63.2 & 69.1 & 76.2 & 84.3 \\
\hline 11. UK** & 48.8 & 50.1 & 51.3 & 52.4 & 53.4 & 54.3 \\
\hline 12. France & 48.8 & 49.7 & 50.5 & 51.2 & 51.9 & 52.5 \\
\hline 13. Philippines & 42.3 & 48.0 & 53.7 & 59.1 & 64.5 & 69.3 \\
\hline 14. Turkey & 36.6 & 41.0 & 44.7 & 47.7 & 50.7 & 53.5 \\
\hline 15. Vietnam & 36.6 & 40.5 & 44.4 & 48.2 & 52.1 & 55.8 \\
\hline 16. South Korea & 40.1 & 40.4 & 40.6 & 40.7 & 40.9 & 41.0 \\
\hline 17. Egypt & 34.1 & 36.0 & 38.3 & 40.9 & 43.9 & 47.4 \\
\hline 18. Italy & 34.5 & 35.8 & 36.2 & 37.2 & 37.5 & 37.7 \\
\hline 19. Spain & 30.5 & 31.6 & 32.3 & 33.0 & 33.5 & 33.9 \\
\hline 20 Canada & 27.7 & 28.3 & 28.8 & 29.4 & 29.9 & 30.4 \\
\hline 21. Argentina & 25.0 & 27.1 & 29.0 & 29.8 & 30.5 & 31.1 \\
\hline 22. Colombia & 24.2 & 26.5 & 28.6 & 29.4 & 30.5 & 31.3 \\
\hline 23. Thailand & 22.7 & 24.3 & 26.0 & 27.6 & 29.1 & 30.6 \\
\hline 24. Poland & 22.6 & 22.9 & 23.3 & 23.7 & 24.0 & 24.3 \\
\hline 25. South Africa & 20.1 & 22.7 & 25.0 & 27.2 & 29.2 & 30.9 \\
\hline Worldwide*** & $2,692.9$ & $2,892.7$ & $3,072.6$ & $3,246.3$ & $3,419.9$ & $3,600.2$ \\
\hline \hline
\end{tabular}

Note: Individuals of any age who use the internet from any location via any device at least once per month; * excludes Hong Kong; ** forecast from Aug 2014; *** includes countries not listed.

Source: Agomuoh, 2014.

In Poland, the total number of Internet users in January 2016 amounted to 25.7 million people, accounting for $67 \%$ of the Polish population with access to the Internet by broadband connection and mobile devices (telephones, smartphones, tablets, mobile broadband modems (with a SIM card)). There were 15 million active users of social media in Poland (36\% of the population), and 59 million active cellular phones. $94 \%$ of adult Poles used cellular phones, 59\% used smartphones, 77\% used laptops or desktop PCs, and 24\% used tablets. Polish citizens spend an average of 4 hours and 25 minutes 
browsing via desktop PCs or laptops, and an average of 1 hour and 17 minutes on mobile devices each day. $28 \%$ of Poles use mobile banking services through smartphones and tablets. E-commerce ${ }^{1}$ is also very popular in Poland (Digital in 2016, 2016).

All this shows that modern ICT continues to develop and has an immense global potential which is still growing. The importance of cellular phones is enormous, in particular of the increasingly popular and less expensive (and, consequently, more popular) smartphones, the parameters and functionality of which continue to improve. If this trend is maintained, they will become the most common method of connecting with the Internet. The global network, which is increasingly often accessed through cellular phones, has at least four essential functions in society: information, communication, commerce and marketing. Traditional media can also perform all these functions, but the range and attractiveness of online communication is considerably greater when using cellular phones. The essential function of the Internet is to provide information. Thanks to the world wide web, it is an excellent carrier of all kinds of information, incorporating text, sound, video and graphics. Rapid access and unlimited resources give the Internet an unparalleled advantage over traditional means of communication, especially as the Internet is always "to hand" thanks to cellular phones. Information flow is faster and more widespread than ever before.

The first communication tool applied online was e-mail, which allowed millions of Internet users to get in touch and exchange information. Today, electronic mail is accompanied by a host of other options, such as video transmissions via Skype, online communicators such as Twitter, and social media networks such as Facebook. According to statistics compiled by Mobirank, Facebook has over 1.4 billion users per day, which translates into 2.13 billion users per month. The popularity of other applications, such as YouTube, Messenger, WhatsApp, Instagram and Snapchat is also growing (with the exception of China, which has its own equivalents). The enormous potential for the distribution of products and services was quickly noticed in the e-commerce sector. Virtually every product and service can be ordered online, including those which are difficult or impossible to find in traditional shops. The net has become a universal carrier of information about products, prices, delivery times and many other useful details. The Internet has also enabled e-marketing, which has become the most rapidly developing advertising distribution channel. Easily available modern tools and resources, such as big data, allow producers to reach their defined target group of consumers quickly. By way of a range of websites, forums, portals, blogs, etc., the Internet has changed, or rather revolutionized, work and leisure. The net has reformed learning and studying, created a range of new opportunities for human development, and set new standards in human relations as well as professional and social activity. All this has also produced certain threats which need to be examined, assessed and forecasted (Cieciura, 2012; Tadeusiewicz, 2002; Goban-Klas, 2005; Facebook ma już..., 2018).

${ }^{1}$ E-commerce is one of the fastest developing types of business activity in Poland. The development of the Internet (range and speed) has been accompanied by the corresponding development in telecommunication networks and purchases of improving, cost-efficient software and hardware. The price of stationary and mobile devices with connections to the Internet is falling in Poland, whereas their quality has grown exponentially, which is the case across the world. For more see: Historia 20 lat Internetu w Polsce, 2011; Kare-Silver, 2002; Dwornik. 


\section{The essence of the information society}

As the significance of innovation in human life increased rapidly in the second half of the $20^{\text {th }}$ century, the emergence of a new type of society, dubbed the information society, was observed. This term was first used by a Japanese author, Tadao Umesao, in his 1963 article about the theory of social evolution based on IT. Five years later, it was popularized by Kenichi Koyama in his paper Introduction to Information Theory. The term "information society" (IS) is used interchangeably with "knowledge society," because the information referred to in the former term encompasses knowledge gathered in the process of research and study rather than merely "information" which is spread virtually ${ }^{2}$ (Grodzka, 2009, p. 10).

It is clearly difficult to define the information society. Global literature on this topic refers to numerous definitions of IS. Martin Bangemann seems to have coined the most popular, saying that "the information society is prepared and able to use IT systems. It effectively uses telecommunication services to transfer information and process it remotely" (Bangemann, 1994).

Cassey, in turn, defines IS as society for whose operation information is the crucial socio-economic element (Cassey, 2001, p. 34).

Szczepański emphasizes that information is intensely used in economic, social, cultural and political life. In his opinion, IS is characterized by the use of different means of communication and information processing, and by the fact that those means contribute to national income. They also provide livelihoods for the majority of society (Szczepański, 2002, p. 170).

According to Siciński, IS emerged in response to an increased demand for information in every field of life and the development of new media and tools for information processing, editing and transmission (Siciński, 1999, p. 20).

Tomasz Goban-Klas views the information society as that "which is in possession of advanced means of information processing and communication, where these means form the basis of national income and provide livelihoods to the majority of society" (GobanKlas, 1999, p. 53).

The same author also emphasizes that an information society "does not only mean a society in which computers and the Internet are in every home, but a society which is able to receive information (speaks foreign languages) and classify and use information provided by different sources, and that makes extensive use of multimedia in all aspects of individual and collective life" (Goban-Klas, 2007, p. 147).

The multitude of definitions does not help to grasp the essence of the new social model. Nevertheless, some features can be noted that are shared by different and independent attempts to explain the phenomenon of the information society. These charac-

2 The term Information Society (Jap. johoka shakai) was first used in 1963 by a Japanese sociologist, Tadao Umesao. It spread when the dissertation Introduction to Information Theory by Keinichi Koyama was published. The first detailed description of these kinds of social changes was presented by Yoneji Masuda in his publications. He argued that by the end of the $20^{\text {th }}$ century, a new civilization of intangible character would emerge. He believed that this type of civilization would be named the information civilization and that information societies would turn away from the consumption of physical goods towards intangible goods. 
teristics include information processing, the quality of information and pace of its transmission, the ability to use information to increase economic competitiveness, and faster access to exhaustive and more credible information provided by numerous sources that are independent from one another, thereby facilitating the process of effective decision making. Members of an information society enjoy wide access to information, research and communication and therefore are able to organize themselves more easily, participate in social life to a greater extent, find jobs more effectively, and take advantage of e-education, e-business, e-commerce, e-administration, e-entertainment and many other forms of e-activities. They can also exploit the full potential of the so-called e-democracy (Strategia Rozwoju ...; Zacher, 2006; Papińska-Kacperek, 2008).

An information society, which assigns particular importance to "intellectual technologies" that are present in the sectors of education, finance, insurance, healthcare, culture and academia, is distinguished by the following:

- production - an information society produces huge amounts of information and requires the creation of new information and its use on a mass scale;

- storage - technological advancements offer enormous capacity for the storage of information;

- transmission - technology facilitates the transfer of information, regardless of spatial or temporal limitations;

- downloading - technology allows every interested individual to download any information from the net;

- use - the Internet as a source of information is available without limits and restrictions (Krzysztofek, 2002, p. 18).

An information society performs a number of functions, such as:

- education: ensuring universal access to knowledge and persuading society that it is crucial to advance one's skills and qualifications;

- communication: the emergence of new personal bonds;

- socialization and activation: providing incentives to people who have been excluded from society and the labor market for various reasons;

- participation: the opportunity to take part in political life;

- organizing function: creation of a teleinformation market which facilitates the development of competition;

- protection and monitoring: introduction of barriers that protect people against cyber-crime (Krzysztoszek, 2002, p. 18).

At least three criteria need to be fulfilled in economic terms for a society to be classed as an information society: information has to become an economic category and the production and circulation of information have to become economic activities. At the same time, "an information society is identified as such if information processing by means of ICT constitutes a considerable economic, social and cultural value." All types of social activity should be supported by information technologies while over $30 \%$ of workforce should be employed in the information sector (Strategia Rozwoju...).

Business in an information society is characterized by constantly evolving methods of organization and models of professional life. Thanks to the latest technologies, knowledge-intensive activities (in particular knowledge-intensive services) spread widely. Shared services centers offering outsourcing and offshoring gain popularity, as does 
so-called 'homeworking' (or 'home office,' working from home via computers and the Internet). Advanced, modern education ensures IT training for all, as well as teaching within an e-school framework (e-classes, e-course books, etc.). The labor market, which has witnessed advancing automation, miniaturization and digitalization since the late 1960s, and, more recently, robotization, requires increasingly qualified workers, who are able to skillfully use information and communication technologies, and continue to develop their qualifications and competence in this respect. This should prevent social marginalization and increased unemployment, as well as create new workplaces. ${ }^{3}$

Information and telecommunication technologies have become a strategic element which stimulates economic growth and employment. Different economic results achieved by different countries can to a large extent be explained in terms of investment in ICT, its scale and the ability to use it amongst the general population. This should be facilitated by efficient public administration (e-administration). Developed countries in South-East Asia, especially South Korea, Japan, Hong Kong and Singapore, the United States, Canada and certain EU member states (especially Scandinavia) are the best exemplification of the development opportunities provided by the e-economy and e-society (Grodzka, 2009, p. 35).

\section{Digital exclusion - causes and outcomes}

At present, access to the Internet is more than a mere convenience; it frequently is a necessary condition to fully take part in social, cultural and professional life. It is increasingly difficult for individuals to function socially without the Internet. Internet-based modern technologies are among the essential determinants of the dynamic development of knowledge- and information-based economies and societies. While these technologies offer a range of advantages, they also have their shortcomings and pose threats. On the one hand, they contribute to the emergence of a new social model, in which they can be used to improve living conditions and generate economic growth; on the other, they generate unprecedented new problems and barriers, such as cyber-violence, cyber-crime and cyber-terrorism. One can easily become a target of hacking, online fraud or extortion as a result of unauthorized access to sensitive data. Minors and/or emotionally immature individuals can easily access pornographic content, which may result in deprivation-related behavior. An even greater risk is associated with relatively simple and anonymous access to darknet (deep web) websites, featuring, first and foremost, pedophilic content. Another problem concerns addictions to new technologies, especially to smartphones. "No mobile phobia," also named nomophobia, is viewed as a new civilizational disease

${ }^{3}$ It should be remembered that automation has created more jobs than it has rendered obsolete so far, although it is true that the people who lose jobs due to automation rarely find jobs in the new sectors created as a result of automation. In the same way, rapidly developing e-commerce, embodied by its US leaders - Amazon, eBay and Walmart trade websites (as well as Chinese J.D.com and Alibaba, or Japanese Rakuten), has increased rather than slashed the overall number of both white-collar and blue-collar employees. Yet autonomous vehicles, drones and other modern unmanned robots can pose a considerable threat to human labor in the future. They have already fueled discussion on whether or not this vision of the future should be pursued (e.g. Elon Musk and Bill Gates who demand that robots be taxed) (Ip, 2017). 
which could affect $70 \%$ of global population (based on the fact that Zenith Mobile Advertising Forecast estimated that around $70 \%$ of people own smartphones in 2018). In practice, this disorder most often affects young people under 25 years of age. Another serious problem is the formation of groups of people incapable of taking part in social and economic life, thereby becoming partly or completely excluded (the phenomenon of digital illiteracy and digital exclusion/divide) (Yildirim, 2014; Understanding the digital divide..., 2001; Hargittai, 2003).

One of the problems related to the rapid development of modern technologies concerns the phenomenon of digital exclusion (e-exclusion) which at present affects approx. 3.5 billion people to a greater or lesser extent. In Poland, it affects ca. $30 \%$ of the population. The concept of digital exclusion is derived from that of social exclusion; it means that an individual or social group is a member of a community (most often of a state), but cannot take part in many significant fields of community life, either partially or completely. This limitation does not only stem from the beliefs of the excluded, but also from matters that are partially or completely beyond their control. This exclusion may pertain to work, consumption, business, politics, or participation in the culture and life of local communities. Therefore, digital exclusion is about the lack of access to specific resources which are necessary for normal participation in society. The 'digital divide' refers to the differences between people who enjoy regular access to digital and information technologies and can use them effectively, and those who do not have access to and/or cannot use ICT. These differences are related to physical access to ICT as well as to the soft skills which are necessary to use it. Using the Internet can have very positive outcomes, such as improved professional status, maintaining activity on the labor market, increased sales of goods and services, a wider, better and more cost-effective range of goods and services available to consumers/prosumers, increased social and political activity, and taking part in cultural and social life, as well as entertainment.

These advantageous outcomes enjoyed by Internet users are combined with a lack of opportunities for those who do not use the net, and the increasing numbers of obstacles that they face on an everyday basis. Since a growing number of activities and functions are transferred to the Internet, digital exclusion may result in real difficulties in performing everyday tasks. The Internet has become such an important instrument to access information and knowledge that the people who do not use it, as well as those who do not have adequate skills, stand a higher risk of social and economic exclusion. E-exclusion is both about lack of physical access to the Internet (access to infrastructure, hardware and software, as well as their quality and cost) and about a whole range of psychological factors (fear and anxiety about using the Internet, motivation to do so or lack thereof, sufficiency of e-skills) (Wykluczenie cyfrowe w Polsce, 2015).

In 2013, Poland was sixth from the bottom among EU countries regarding use of the Internet. The surveys carried out by the Public Opinion Research Center (CBOS) annually demonstrate that the number of regular Internet users has recently reached $67 \%$. However, Poland is still lagging way behind Sweden and Denmark, where the number of Internet users has exceeded 95\%. Following the diagnosis drafted by the Ministry of Administration and Digitization under the National Broadband Plan, this was caused by a relatively low level of development of broadband infrastructure compared to the ma- 
jority of other EU members, as well as the low level of use of the infrastructure that was available (Narodowy Plan Szerokopasmowy, 2014).

Nevertheless, significant and advantageous changes in this field could be seen over the last two decades. Ten years ago, Internet users accounted for only $25 \%$ of adult Poles. Five years later, over half of them used the net. Still, over one third of Poles continue to be digitally excluded. In 2014, slightly over one fourth of households $(25.2 \%)$ did not have access to the Internet. Both access to the Internet and the kind of connections available in households differed with respect to the type of household, place of residence and urbanization rate. Access to the Internet and computers in households strongly depended on the type of family. Households where there were no children made up a large proportion of those without access to the Internet. In 2014, the difference between these two types of households amounted to 28 percentage points. This is because children use the Internet most frequently (the largest proportion of Internet users is recorded in the 12-15 age group, where they account for over $97 \%$ ). Households without children are typically those of the elderly, where the proportion of Internet users is the lowest. Lack of access to the Internet also correlates with living in rural areas or those with low rates of urbanization, yet the differences were much less significant in this case. The difference between residents of large cities and those of rural areas was only 8 percentage points, and the difference between residents of areas with high and low urbanization rates was even smaller, just 7 percentage points. In this case, failing to use the Internet was the outcome of both a low level of IT competence and limited access to transmission infrastructure. Respondents indicated no need to use the Internet, or no motivation, as the top reason (59.1\%) for their lack of access to the Internet. The second most frequently indicated reason was a lack of digital skills, mentioned by $44.8 \%$ of respondents. Psychological factors included reluctance to use the net (5.7\%) and the fear of losing privacy and security concerns $(2.3 \%)$. The lack of a computer was less and less frequently associated with financial reasons (Wykluczenie cyfrowe w Polsce, 2015).

The results of the above-mentioned survey reflect a distinct difference between psychological factors, such as the motivation and skills required to use a computer, and technological factors, which are considerably less significant than a decade ago. The crucial criterion, and a barrier, is age. Only $15 \%$ of respondents in the $65+$ age group use the Internet in Poland, compared to as many as $97 \%$ in the $18-24$ age bracket, and $95 \%$ in the $25-34$ age group. An enormous difference is recorded between the youngest (18-24) and the oldest (65+) age groups; as much as 82 percentage points (Wykluczenie cyfrowe w Polsce, 2015).

Digital competence increases in line with the level of education. Amongst people with only elementary education, the proportion of Internet users is the lowest (18\%), and the largest proportion (94\%) is noted for those with university education. The last significant criterion is place of residence. Although its influence on access to the Internet is the smallest, a difference of 30 percentage points can be noted between rural areas (56\%) and large cities (86\%). The survey by the Public Opinion Research Center makes it possible to identify the basic criteria of social exclusion with respect to digital competences, namely age, education and, to a lesser extent, material status and place of residence ${ }^{4}$ (Wykluczenie cyfrowe w Polsce, 2015).

${ }^{4}$ Only four years ago, nearly 10 million Poles either did not use the Internet at all, or did so only occasionally. By 2017, this number had dropped to slightly over 9 million. In 2013 , nearly $80 \%$ of the 
Having analyzed the above, we may arrive at the conclusion that digital exclusion is not just about what proportion of people do not use the Internet, and that providing universal access to the Internet does not automatically translate into its proper use. The majority of Internet users treat it as a source of entertainment and a pastime, first and foremost. Banking services and e-commerce are also becoming increasingly popular. Yet, in terms of the labor market and e-administration, the Internet continues to be relatively rare. Given the progressing digitalization of all fields of life and the complexity of digital exclusion, central administration, local governments and social organizations are facing a huge challenge in ensuring that those threatened by exclusion do not miss out on the opportunities offered by the Internet. Dedicated campaigns are required, in particular in the field of employment and use of public services and education, to remove both technical and psychological barriers (Wykluczenie cyfrowe w Polsce, 2015).

Regarding public services (e-administration), two program documents professionally drafted by the Polish Ministry of Digitization deserve special attention: From paper to digital Poland and the Program of Integrated National Informatization. They conclude that the most prominent issue causing digital exclusion in Poland involves mental barriers and the lack of need to use new technologies. Other factors include the age of the excluded, the presence of children in the household (their absence may contribute to e-exclusion), place of residence and level of education. The statistics of the Ministry of Digitization show that only $10 \%$ of people in the 16-74 age bracket have highly developed digital skills, and just $29 \%$ have skills at an intermediate level. The rest of the population has low or no skills whatsoever. Lack of access to the net produces negative social outcomes. It limits one's access to culture, employment, commerce and public services. Digital integration of a larger proportion of Poles would facilitate improved opportunities to find employment or increase one's income, which translates to higher payments into the Polish Healthcare and Social Security Systems. On the basis of the PwC methodology, which is appreciated in Europe, e-exclusion has been calculated to burden the Polish budget with ca. PLN 24 billion per year (Raporty).

Approximately 9 million Poles either do not use the Internet at all, or do so only occasionally. The Polish economy and society will not be able to develop a proper knowledge-based economy or information society if this does not change. The main barrier that needs to be overcome is the fear of digital technology, rather than physical access to the Internet. That is why the Polish government has repeatedly declared that the propagation of digital skills will become a development priority in the new EU budget for 2014-2020. The education sector has carried out a pilot program entitled Digital school in order to facilitate the implementation of a digital modernization program for schools by 2020 . PLN 4.5 billion was earmarked for this purpose. However, during the $2^{\text {nd }}$ Congress of Digital Poland, experts warned that analysis of the adopted operating

13 million Poles aged 50+ did not use the Internet at all. Nearly $60 \%$ of Poles could not use a computer, or were able to perform only the one or two simplest tasks with it. As many as $35 \%$ had none of the skills required for online activity. Over $47 \%$ of people who did not use the Internet live in rural areas. Other statistics show that: (1) $68 \%$ of them have elementary or vocational education; (2) $49 \%$ were pensioners, (3) $73 \%$ were in the $45+$ age group. In 2013, digital exclusion pertained to $78 \%$ of people aged $50+$. The highest rate of digital exclusion in Poland was recorded among people aged 55+, farmers, the disabled, the poor, and poorly educated people (Narodowy Plan Szerokopasmowy, 2014). 
programs showed that the actual amount would be considerably smaller, amounting to only PLN 900 million. The amount of EU funds allocated to the digital modernization of schools was thus five times smaller than originally planned. PLN 900 million (instead of the PLN 4.5 billion declared at the beginning) will provide support for only $8 \%$ of schools and training for only $2.5 \%$ teachers (Wykluczenie cyfrowe w Polsce, 2015).

Further attempts to develop the digital competence of teachers are necessary. Too few schools in Poland are able to run electronic classes, using such multimedia tools as e-boards, e-course books, tablets or laptops (e.g. Classmate PC). IT classes in many Polish schools continue to involve simply teaching basic programs (e.g. Paint) or the construction of computers, instead of teaching the basics of programming or using more advanced applications. The level of programming skills in Poland is very low: only 9\% of Poles declare that they have these skills. The global demand for IT experts and software developers is immense. Training teachers and the efficient education of children and adults are therefore among the essential elements of combating digital exclusion in Poland (Wykluczenie cyfrowe: edukacja ...; Popiołek, 2013, pp. 310-320; Jastrzębska, Jastrzębska, 2012, pp. 91-104).

It is of equal importance to run advocacy campaigns, professional workshops and training, in particular in smaller towns and villages, especially aimed at people over 50 and the poorly educated. These people need to be educated and stimulated; they need to be shown what advantages the net has in everyday life, starting with the simplest operations, and emphasizing the psychological rather than technical aspects of IT, at least at the beginning (Wykluczeni cyfrowo, 2015, pp. 10-11).

Graph 3. TOP 20 mobile applications in Poland (December 2016) The most popular Android and iOS applications in Poland (December 2016)

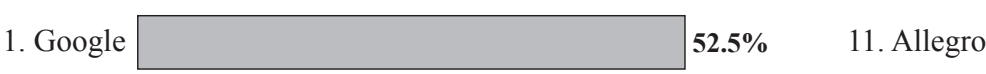

$11.3 \%$

2. YouTube

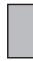

3. Messenger

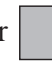

4. Facebook

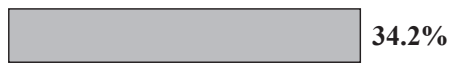

5. Mapy Google

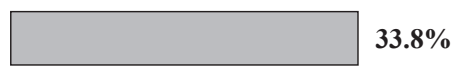

6. Gmail

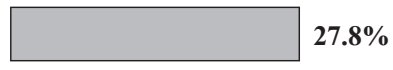

7. Dysk Google

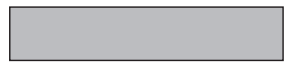

$26.2 \%$

$16.2 \%$

8. Google+

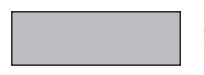

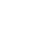

9. OLX.pl

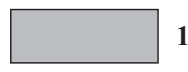

$14.3 \%$
$48 \%$

12. Gry Google Play

13. Google Photos

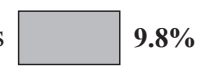

14. Clingo

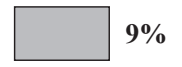

15. Instagram

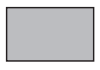

$8.4 \%$

16. Skype

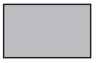

$8.3 \%$

17. Hangouts $6.2 \%$

18. Google Muzyka

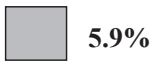

19. Snapchat $5.5 \%$

10. WhatsApp $12.8 \%$
20. Google translator $4.7 \%$

Source: https://mobirank.pl/2017/01/15/top-20-najpopularniejszych-aplikacji-mobilnych-polsce-2016/. 


\section{Conclusions}

People who are digitally excluded find it much more difficult to overcome psychological rather than technical barriers to having access to the Internet and learning basic computer skills. Over $80 \%$ of Poles aged $50+$ choose not to take part in any training sessions on how to use the tools of the "digital world" in everyday life because of this fear, anxiety and lack of faith in their own skills. This situation calls for urgent improvement, because these people usually need only basic digital skills to be able to take advantage of and benefit from computer applications. In the modern information society, a lack of basic knowledge about computers translates into partial or total digital illiteracy and makes it difficult to perform a range of everyday tasks. It is therefore essential in Poland to prevent digital exclusion. People who do not use the Internet are socially and professionally limited, or virtually handicapped, which results in quantifiable economic losses. This translates to lower creativity and innovativeness and reduced revenue of state budget, and impedes the competitiveness of the economy and the development of a post-modern, post-industrial social model (Wykluczenie cyfrowe: edukacja..., 2015).

\section{Bibliography}

3 miliardy internautów w 2015 r., Polska w Top 25 (2014), http://www.wirtualnemedia.pl/artykul/3miliardy-internautow-w-2015-r-polska-w-top-25, November 21, 2017.

Agomuoh F. (2014), Internet Expansion: Mobile Devices In Developing Markets To Push Web Usage Past 3 Billion In 2015, 20.11.2017.

Bangemann M., Europe and the Global Information, http://www.umic.pt/images/stories/publicacoes20080 1/raport_Bangemanna_1994.pdf, January 22, 2018.

Cassey M. (2001), Europejska polityka informacyjna. Wyzwania i perspektywy dla administracji publicznej, Toruń.

Cieciura M. (2012), Wybrane problemy spoteczne i zawodowe informatyki, Warszawa.

Digital in 2016 (2016), http://wearesocial.com/uk/special-reports/digital-in-2016, last access: May 09.

Digital in 2017: Global Overview (2017), https://wearesocial.com/blog/2017/01/digital-in-2017-global-overview, January 22.

Dwornik B. (2008), To juz 17 lat. Zobacz historię Internetu w Polsce, http://www.manager.money. pl/news/artykul/to;juz;17;lat;zobacz;historie;internetu;wpolsce,130,0,408706 e.html, May 09, 2017.

Facebook ma już 1,4 mld użytkowników dziennie (2018), https://mobirank.p1/2018/02/01/facebook-majuz-14-mld-uzytkownikow-dziennie-4q2018/, January 07.

Goban-Klas T. (1999), Społeczeństwo informacyjne: Szanse, zagrożenia, wyzwania, Kraków.

Goban-Klas T. (2007), Od społeczeństwa industrialnego do społeczeństwa informacyjnego, Kraków.

Goban-Klas T. (2005), Spoteczeństwo medialne, Warszawa.

Grodzka D. (2009), Poczqtki społeczeństwa informacyjnego, in: D. Grodzka, Społeczeństwo informacyjne, Warszawa.

Hargittai E. (2003), The Digital Divide and What To Do About It, Sociology Department Princeton University, http://www.eszter.com/research/pubs/hargittai-digitaldivide.pdf, October 27, 2017. 
Historia 20 lat Internetu w Polsce (2011), http://www.gazetaprawna.pl/wiadomosci/artykuly/ 538332,historia_20_lat_internetu_w_polsce.html, August 15, 2017.

https://www.sas.com/pl_pl/insights/big-data/what-is-big-data.html, August 15, 2017.

Ip G. (2017), Pracownicy, nie lękajcie się (robotów), „The Wall Street Journal”, reprinted by “Gazeta Wyborcza," October 27.

Jastrzębska A., Jastrzębska W. (2012), Wykluczenie cyfrowe - przyczyny, zagrożenia i bariery jego pokonania. Studium przypadku, "Nierówności Społeczne a Wzrost Gospodarczy," 25, pp. 91-104.

Krzysztofek K. (2002), Spoteczeństwo informacyjne a rozwój człowieka, in: Polska na drodze do globalnego społeczeństwa informacyjnego, ed. W. Cellary, Warszawa.

Kare-Silver M. (2002), E-szok. Rewolucja elektroniczna w handlu, Warszawa.

Narodowy Plan Szerokopasmowy (2014), Ministerstwo Administracji i Cyfryzacji, January.

Papińska-Kacperek J. (2008), Społeczeństwo informacyjne, Warszawa.

Popiołek M. (2013), Wykluczenie cyfrowe w Polsce, "Nierówności Społeczne a Wzrost Gospodarczy," 32, pp. 310-320.

Raport dotyczacy cyfrowych trendów spolecznych w świecie w roku 2016 (2016), http://wearesocial. com/uk/special-reports/digital-in-2016, February 13.

Statystyki dotyczqce liczby użytkowników Internetu na świecie (2016), http://www.statista.com/statistics/273018/number-of-internet-users-worldwide/, February 13.

Senkus P. (2013), Zarzadzanie i dowodzenie z wykorzystaniem orientacji procesowej. Sektor prywatny, sektor publiczny, sektor non profit, Wydawnictwo Difin.

Szczepański M. (2002), Zrozumieć rozwój. Od społeczeństw tradycyjnych do informacyjnych, Katowice.

Siciński A. (1999), Społeczeństwo informacyjne: próba nazwania naszych czasów. W drodze do społeczeństwa informacyjnego, Warszawa.

Strategia Rozwoju Spoleczeństwa Informacyjnego w Polsce do 2013 roku, http://www.umwd.dolnyslask.pl/fileadmin/user_upload/spoleczenstwo_informacyjne/dokumenty/Strategia_Rozwoju_ Spoleczenstwa_Informacyjnego_w_Polsce.pdf, October 15, 2017.

Tadeusiewicz R. (2002). Społeczność Internetu, Warszawa.

Understanding the Digital Divide (2001), Organisation For Economic Cooperation And Development, OECD, https://www.oecd.org/sti/1888451.pdf.

Wykluczenie cyfrowe w Polsce (2015), Kancelaria Senatu, Biuro Analiz i Dokumentacji, Zespół Analiz i Opracowań Tematycznych, December.

Wykluczenie cyfrowe. Problem, który dotyczy 9 mln Polaków, (2015), https://www.money.pl/gospodar$\mathrm{ka} /$ wiadomosci/artykul/wykluczenie-cyfrowe-problem-ktory-dotyczy-9,77,0,1951309.html.

Wykluczenie cyfrowe: Edukacja ważniejsza od sprzętu (2015), http://www.portalsamorzadowy.pl/spoleczenstwo-informacyjne/wykluczenie-cyfrowe-edukacja-wazniejsza-od-sprzetu,71550.html.

Wykluczeni cyfrowo (2012), Badanie realizowane w ramach kampanii społecznej „Niech internetowa moc będzie z Tobą" finansowanej ze środków Ministerstwa Administracji i Cyfryzacji (C) TNS October 2015, pp. 10-11.

Wykluczenie cyfrowe: Edukacja ważniejsza od sprzętu (2015), http://www.portalsamorzadowy.pl/spoleczenstwo-informacyjne/wykluczenie-cyfrowe-edukacja-wazniejsza-od-sprzetu,71550.html.

Zacher L. W. (2006), Społeczeństwo informacyjne. Istota, rozwój, wyzwania, Warszawa.

Yildirim C. (2014), Exploring the dimensions of nomophobia: Developing and validating a questionnaire using mixed methods research, Iowa State University, Digital Repository, Graduate Theses and Dissertations, http://lib.dr.iastate.edu/cgi/viewcontent.cgi?article=5012\&context=etd, November 1, 2017. 


\section{Wykluczenie cyfrowe jako bariera w rozwoju społeczeństwa informacyjnego. Przykład Polski}

\section{Streszczenie}

Nie ma wątpliwości, że transformacja cyfrowa stała się najważniejszym megatrendem cywilizacyjnym naszych czasów. Sztuczna inteligencja (artificial intelligence/AI), maszyny i pojazdy autonomiczne, Internet rzeczy (IoT), technologia finansowa (finacial technology/FinTech), smart investing (SI) oraz analiza i przetwarzanie dużych zbiorów danych typu Big data, stanowią najnowsze, ale nie jedyne przejawy tego trendu. W ich efekcie powstało i stale kształtuje się społeczeństwo informacyjne (IS) - nowy typ relacji społecznych, wyraźnie odróżniający się od poprzednich form organizacji życia ludzkiego. Kluczową rolę odgrywa w nim informacja i wiedza umożliwiające budowę modelu „gospodarki opartej na wiedzy” (Knowledge Based Economy/KBE), czyli systemu, który opiera się na szybszym i skuteczniejszym niż do tej pory gromadzeniu, przekazywaniu i przetwarzaniu informacji oraz wykorzystywaniu tych elementów w postaci zdobytej wiedzy na potrzeby szybszego wzrostu gospodarczego. Niestety zjawisko wykluczenia cyfrowego nadal występuje, także w Polsce. Autor w prezentowanym artykule dochodzi do wniosku, że dla osób wykluczonych cyfrowo, problemem znacznie większym niż techniczna bariera dostępu do sieci i opanowanie podstawowych zasad obsługi komputera jest przełamanie bariery psychologicznej. Stan ten należy szybko poprawić, bowiem w ponowoczesnym społeczeństwie informacyjnym, brak podstawowego zrozumienia zasad działania komputera generuje problem częściowego lub całkowitego analfabetyzmu cyfrowego i skutecznie utrudnia odnalezienie się w realiach życiowych. Brak kontaktu z Internetem ogranicza, czasem wręcz upośledza społecznie i zawodowo, powodując wymierne straty ekonomiczne. Przekłada się na niższą kreatywność i innowacyjność ludzką, powoduje brak przychodów budżetowych, stanowiąc barierę na drodze do zwiększania konkurencyjności gospodarki i budowy ponowoczesnego, postindustrialnego modelu społecznego. Głównym celem badawczym prezentowanego artykułu jest ukazanie przyczyn zjawiska wykluczenia cyfrowego w Polsce oraz sposobów przeciwdziałania jego negatywnym skutkom społeczno-ekonomicznym. W trakcie prowadzonych badań najczęściej posługiwano się metodą analizy przyczynowo-skutkowej i instytucjonalno-prawnej. Wykorzystano też elementy metody decyzyjnej, historycznej, komparatystycznej i badań statystycznych.

Słowa kluczowe: wykluczenie cyfrowe, media społecznościowe, handel elektroniczny, Internet, PKB, rozwój społeczno-ekonomiczny, globalizacja 
